\title{
ANALISIS KEMAMPUAN KOMUNIKASI MATEMATIS SISWA DALAM MENYELESAIKAN SOAL HIGHER ORDER THINKING SKILL (HOTS)
}

\author{
Oleh :
}

\author{
Muhammad Rizal Usman ${ }^{1)}$, Sri Satriani ${ }^{2)}$ \\ ${ }^{1}$ Fakultas Keguruan dan Ilmu Pendidikan, Universitas Muhammadiyah Makassar \\ ${ }^{2}$ Fakultas Keguruan dan Ilmu Pendidikan, Universitas Muhammadiyah Makassar
}

\begin{abstract}
Abstrak
Penelitian ini bertujuan untuk mengetahui kemampuan komunikasi matematis siswa dalam menyelesaikan soal Higher Order Thinking Skill (HOTS) Kelas IX A SMP Negeri 13 Makassar. Jenis penelitian ini adalah penelitian deskriptif dengan menggunakan pendekatan kualitatif. Pengambilan subjek penelitian dilakukan dengan memberikan tes soal esai pada siswa kelas IX A yang kemudian dari hasil tersebut 3 subjek penelitian berdasarkan kategori yang telah ditentukan. Instrumen yang digunakan adalah tes tertulis kemampuan komunikasi matematis yang memuat 3 butir soal dengan materi lingkaran tipe HOTS dan pedoman wawancara. Hasil penelitian kemampuan komunikasi siswa dalam menyelesaikan soal HOTS yaitu pada ketiga subjek menunjukkan hasil yang berbeda-beda setiap subjek. Subjek S1 memiliki kemampuan komunikasi matematis yang paling tinggi secara tertulis dan lisan dengan mendapatkan 42 skor berdasarkan dari hasil analisis yang telah dilakukan. Kemudian, subjek 22 mendapatkan 38 skor dan subjek S3 memiliki kemampuan komunikasi matematis yang paling rendah diantara ketiga subjek yang ada yaitu mendapatkan 34 skor. Berdasarkan dari hasil analisis data dapat disimpulkan bahwa ketiga subjek yaitu S1, S2, dan S3 memiliki kemampuan komunikasi matematis yang baik dalam menyelesaikan HOTS.
\end{abstract}

Kata kunci-Analisis, Higher Order Thinking Skill (HOTS), Kemampuan Komunikasi Matematis

\begin{abstract}
This study aims to determine students' mathematical communication skills in solving Higher Order Thinking Skill (HOTS) questions for Class IX A SMP Negeri 13 Makassar. This type of research is descriptive research using a qualitative approach. Taking the research subjects was done by giving essay tests to class IX A students which then from these results 3 research subjects based on predetermined categories. The instrument used is a written test of mathematical communication skills that contains 3 questions with HOTS type circle material and interview guidelines. The results of the research on students' communication skills in solving HOTS questions, namely on the three subjects, showed different results for each subject. S1 subjects have the highest mathematical communication skills in writing and orally by getting 42 scores based on the results of the analysis that has been done. Then, the S2 subject got 38 scores and the $S 3$ subject had the lowest mathematical communication ability among the three existing subjects, namely getting 34 scores. Based on the results of data analysis, it can be concluded that the three subjects, namely S1, S2, and S3 have good mathematical communication skills in solving HOTS.
\end{abstract}

Keywords - Analysis, Higher Order Thinking Skill (HOTS), Mathematical Communication Skill

\section{PENDAHULUAN}

Matematika merupakan suatu cabang ilmu sangat penting yang harus dimiliki oleh seorang siswa. Matematika merupakan salah satu ilmu dasar, ilmu pengetahuan tentang penalaran logika yang berhubungan dengan bilangan dan bahasa simbolis yang fungsi praktisnya untuk mengekspresikan hubungan-hubungan kuantitatif dan kekurangan, sedangkan fungsi teoritisnya adalah untuk memudahkan berpikir (Wahyuni, 2019:73). Matematika memiliki bahasa tersendiri yang biasa disebut bahasa matematis. Adanya kemampuan komunikasi matematis, maka siswa mampu menyampaikan ide, gagasan dan simbol dalam bentuk matematika baik secara tertulis maupun lisan. Kemampuan komunikasi matematis siswa adalah kemampuan siswa dalam menyampaikan dan menerima gagasan secara lisan maupun tulisan dalam bentuk diagram, gambar, grafik, aljabar dan simbol matematika (Rachmayani, 2014: 16).

Matematika merupakan salah satu mata pelajaran wajib di sekolah yang telah pemerintah tetapkan. Peraturan pemerintah tentang Kurikulum 2013 yang telah ditetapkan oleh pemerintah RI melalui Permendiknas Nomor 22 Tahun 2016 tentang standar proses, tampak jelas bahwa pada siswa diharapkan mampu aktif untuk belajar dan menggali informasi sendiri sehingga mampu untuk mengembangkan pikiran 
yang dimiliki siswa itu sendiri, maka kebijakan pemerintah saat ini siswa dituntut tidak hanya memiliki kemampuan berpikir tingkat rendah atau LOTS (Lower Order Thinking Skill), tetapi kebijakan pemerintah menuntut setiap siswa untuk memiliki kemampuan berpikir tingkat tinggi atau Higher Order Thinking Skill (HOTS).

Tahun 2018 terdapat kebijakan Kemendikbud untuk menganjurkan kepada sekolah-sekolah yang ada di Indonesia untuk menerapkan soal-soal yang bersifat Higher Order Thinking Skill (HOTS) yang membutuhkan kemampuan berpikir tingkat tinggi pada saat ujian nasional. Dari kebijakan pemerintah mengenai hal tersebut, memiliki dampak kepada siswa di sekolah. Siswa dapat memecahkan masalah dan dapat merangsang daya nalar atau merangsang pikiran siswa untuk berpikir tingkat tinggi serta berpikir kritis terhadap suatu masalah. Kebijakan pemerintah dalam menetapkan soal HOTS pada siswa mendapatkan respons yang baik dan ada juga yang merespons buruk. Respons siswa terhadap penerapan hal tersebut, yaitu banyak siswa yang mengeluh tentang rumitnya soal ujian nasional terkhusus pada mata pelajaran matematika. Hal tersebut terbukti dengan adanya data hasil ujian nasional siswa sekolah menengah pertama di Indonesia pada mata pelajaran matematika memiliki rata-rata nilai 56,27 pada tahun 2017. Namun, saat diterapkannya soal HOTS. Maka memiliki rata-rata nilai 53,42 tahun 2018 (kemendikbud 2018). Dari kedua data ujian nasional tersebut dengan tahun yang berbeda maka dapat diketahui nilai ratarata siswa mengalami penurunan. Namun, seperti diketahui dari data tersebut terdapat beberapa siswa mampu untuk menyelesaikan soal HOTS, maka dari itu perlu adanya penyajian analisis kemampuan komunikasi matematis dalam menyelesaikan soal HOTS.

Beberapa hasil penelitian yang telah dilakukan, Mandini (2018) menunjukkan hasil dari penelitian tersebut yaitu kemampuan menuntaskan soal HOTS model TIMSS pada siswa SMP Kabupaten Wonosobo dalam golongan sedang $(85,9 \%)$. Selanjutnya dilihat pada tiap- tiap indikator dari soal HOTS model TIMSS, indikator memadukan ataupun mengsintesis, menganalisis, membagikan alasan, serta menuntaskan permasalahan yang tidak teratur terletak pada golongan rendah yakni menggeneralisasi. Sedangkan untuk kepercayaan diri siswa SMP di kabupaten Wonosobo terletak pada kategori sedang ( 56, 6\%), apabila dilihat tiap- tiap aspek, jika aspek kepercayaan akan kemampuan diri, optimis, objektif, serta bertanggungjawab terletak pada kategori sedang, aspek rasional serta realistis terletak pada kategori rendah. Sedangkan penelitian yang dilakukan. Sedangkan penelitian yang dilakukan oleh Supriadi (2016) menunjukkan bahwa komunikasi tulisan atau jawaban secara tertulis siswa lamban belajar jauh lebih baik dibandingkan komunikasi lisanya, disebabkan karena siswa yang memiliki menjawaban yang tepat tepat jauh lebih banyak dibanding dengan yang memiliki jawabanan yang benar pada komunikasi lisannya. Komunikasi matematis tulispeserta didik lamban belajar pada proses penyelesaian masalah mtematika membutuhkan waktu yang lumayan lama untuk menyelesaikan soal-soal yang diberikan.

Berdasarkan hasil observasi di lapangan yang dilakukan oleh peneliti maka ditemukan bahwa SMP Negeri 13 Makassar merupakan salah satu sekolah yang ada di Sulawesi Selatan yang telah menerapkan peraturan pemerintah dengan mengimplementasikan kurikulum 2013. Pada proses belajar sehari-hari siswa di sekolah tersebut memiliki kemampuan berpikir yang beragam ketika penerapan Kurikulum 2013 dan juga telah menerapkan soal HOTS pada siswa SMP Negeri 13 Makassar. Namun, pada sekolah tersebut belum menerapkan pembelajaran yang mengasah keterampilan berpikir tingkat tinggi yang seharusnya dimiliki oleh siswa.

Peneliti juga prihatin terhadap siswa yang dituntut untuk menguasai semua mata pelajaran, namun siswa tidak memiliki keterampilan dalam memecahkan masalah, berpikir kritis, menciptakan suatu kreativitas yang mampu siswa komunikasikan dengan baik. Sejalan dengan hal tersebut dari hasil observasi peneliti mendapatkan data bahwa proses tingkat berpikir siswa di SMP Negeri 13 Makassar masih sangat beragam dalam memecahkan masalah soal matematika yang berbasis HOTS. Pada proses pembelajaran cenderung siswa hanya mengikuti dan mencatat apa yang telah didapatkan di sekolah tanpa dilatih untuk mengembangkan proses berpikir tingkat tinggi, sehingga siswa mampu mengomunikasikan ide-ide atau gagasan secara baik dan terstruktur dalam bentuk matematika. Seharunya dimiliki oleh setiap siswa untuk mencapai tujuan pemerintah dalam lingkup pendidikan, yaitu tidak hanya memiliki proses berpikir rendah tetapi mampu memiliki cara berpikir tingkat tinggi.

\section{METODE PENELITIAN}

Penelitian ini menggunakan pendekatan kualitatif. Pendekatan Kualitatif adalah metode penelitian yang berdasarkan pada postpositivisme di mana penelitian dilakukan berdasrkan pada objek yang alami. instrumen pada penelitian kualitatif yaitu peneliti itu sendiri. Subjek penelitian ini ialah siswa kelas IX A SMP Negeri 13 Makassar. Instrumen penelitian dalam penelitian kualitatif ini dibagi jadi 2 ialah instrumen utama serta instrumen pendukung. Instrumen utama ialah peneliti itu sendiri, yang merupakan mutlak 
selaku instrumen kunci, perencana, penafsir informasi, pengumpul informasi serta pelapor informasi yang telah diperoleh. Serta instrumen pendukung yaitu Instrumen selain peneliti seperti tes tertulis dan pedoman wawancara.

Teknik pengumpulan data dalam penelitian ini yaitu menggunakan cara yang berbentuk tes tertulis serta memakai metode yang berbentuk wawancara. Tes tertulis dilakukan pada siswa kelas IX A dituntut buat menyusun jawaban secara terurai serta memaparkan gagasannya melalui bahasa tulisan secara lengkap serta jelas. Penjelasan hasil pekerjaan siswa digunakan untuk mengetahui hasil belajar siswa serta memandang mutu respon siswa dalam mengerjakan soal HOTS. Teknik wawancara dilakukan untuk memberikan serangkaian pertanyaan agar mengetahui tingkat kemampuan komunikasi matematis siswa dalam menyelesaikan soal HOTS, serta faktor-faktor lain yang menunjang siswa dalam mengerjakan soal. Adapun acuan untuk menginterpretasikan data perolehan nilai dari hasil tes tertulis kemampuan komunikasi matematis dalam menyelesaikan soal HOTS yaitu sebagai berikut:

\begin{tabular}{ccc} 
Persentase Siswa $=\frac{\text { Jumlah skor siswa semua indikator }}{\text { Skor maksimal semua indikatir }}$ & Tabel 1. Kategori Subjek Penelitian \\
Kelas Interval & Tingkat Kemampuan \\
Nomor & $0<$ Nilai $\leq 20$ & Sangat Rendah \\
\hline 1 & $20<$ Nilai $\leq 42$ & Rendah \\
\hline 2 & $42<$ Nilai $\leq 60$ & Sedang \\
\hline 3 & $60<$ Nilai $\leq 80$ & Tinggi \\
\hline 4 & $80<$ Nilai $\geq 100$ & Sangat Tinggi \\
\hline 5
\end{tabular}

Informasi yang dianalisis pada penelitian ini hasil wawancara siswa serta penjelasan langkah pengerjaan soal HOTS sebagai tes tertulis siswa. Proses analisis data yang dilakukan yaitu (a) mereduksi data; hasil reduksi data kemudian diseleksi lalu dirangkum disesuaikan dengan rumusan masalah yang telah ditetapkan sebelumnya. Setelah itu, data tersebut dipisah-pisahkankan berdasarkan dengan jenis tertentu berdasarkan rumusan masalah yang telah ditetapkan untuk disesuaikan dengan tema dan polanya, (b) Penyajian data; memaparkan data secara jelas, terstruktur dan menyeluruh dengan mencocokkan pola hubungannya, (c) Penarikan kesimpulan; kesimpulan ini disusun dalam bentuk hasil dari penelitian yang telah didapat oleh peneliti.

\section{HASIL DAN PEMBAHASAN [Kapital, Times New Roman 10 bold] Hasil Penelitian}

Pada hasil tes dan wawancara, dapat ditarik sebuah kesimpulan bahwa kemampuan komunikasi matematis S1 pada soal 3 telah terpenuhi dari indikator A1, B, dan C (S13A, S13B, dan S13C). Namun, pada indikator D hanya menyebutkan kesimpulannya saja tapi tidak menuliskan kesimpulan pada lembar jawabannya, maka dari itu indikator D dikategorikan tidak terpenuhi dengan sangat baik.

Tabel 2. Tingkat Kemampuan Matematis pada Siswa S1

\begin{tabular}{ccccccc}
\multirow{2}{*}{ Indikator } & \multicolumn{2}{c}{ Soal Nomor $\mathbf{1}$} & \multicolumn{2}{c}{ Soal Nomor 2 } & \multicolumn{2}{c}{ Soal Nomor 3 } \\
\cline { 2 - 7 } & $\begin{array}{c}\text { Hasil } \\
\text { Analisis }\end{array}$ & Skor & $\begin{array}{c}\text { Hasil } \\
\text { Analisis }\end{array}$ & Skor & $\begin{array}{c}\text { Hasil } \\
\text { Analisis }\end{array}$ & Skor \\
\hline A & ST & 4 & ST & 4 & ST & 4 \\
\hline B & ST & 4 & ST & 4 & ST & 4 \\
\hline C & ST & 4 & ST & 4 & ST & 4 \\
\hline D & ST & 4 & TT & 0 & T & 2 \\
\hline Jumlah & ST & 16 & ST & 12 & ST & 14
\end{tabular}

Catatan: ST (Sangat terpenuhi), T (Terpenuhi), TT (Tidak Terpenuhi)

Dari tabel 2, hasil dari analisis tes soal dan wawancara maka dapat ditarik sebuah kesimpulan bahwa subjek S1 memiliki kemampuan komunikasi matematis yang sangat baik, karena telah memenuhi beberapa indikator mulai dari indikator A, B, C dan D. Berdasarkan dari hasil ketiga soal tersebut S1 
memperoleh jumlah keseluruhan skor 42 dari perolehan nilai pada soal 1 yaitu sebesar 16 skor, pada soal nomor 2 yaitu 12 skor dan pada soal nomor 3 juga mendapakan 14 skor.

Pada hasil analisis jawaban tes dan hasil wawancara pada soal 3, S2 telah memenuhi secara keseluruhan indikator kemampuan komunikasi matematis mulai dari indikator A, B, C dan D (S23A, S23B, S23C dan S23D).

Tabel 3. Tingkat Kemampuan Matematis pada Siswa S2

Soal Nomor $1 \quad$ Soal Nomor 2 Soal Nomor 3

\begin{tabular}{ccccccc} 
Indikator & $\begin{array}{c}\text { Hasil } \\
\text { Analisis }\end{array}$ & Skor & $\begin{array}{c}\text { Hasil } \\
\text { Analisis }\end{array}$ & Skor & $\begin{array}{c}\text { Hasil } \\
\text { Analisis }\end{array}$ & Skor \\
\hline A & ST & 4 & T & 2 & ST & 4 \\
\hline B & TT & 0 & ST & 4 & ST & 4 \\
\hline C & T & 4 & ST & 4 & ST & 4 \\
\hline D & TT & 0 & ST & 4 & ST & 4 \\
\hline Jumlah & T & 8 & ST & 14 & ST & 16
\end{tabular}

Catatan: ST (Sangat terpenuhi), T (Terpenuhi), TT (Tidak Terpenuhi).

Dari tabel 4.5. secara keseluruhan hasil dari analisis tes dan wawancara maka dapat ditarik sebuah kesimpulan bahwa subjek S2 memiliki kemampuan komunikasi matematis yang sangat baik, karena telah memenuhi beberapa indikator mulai dari indikator A, B, C dan D. Berdasarkan dari hasil ketiga soal tersebut S2 memperoleh jumlah keseluruhan sebanyak skor 38 dari perolehan nilai pada soal 1 yaitu sebesar skor 8 , pada soal 2 yaitu skor 14 dan pada soal 3 juga mendapakan skor 16. Kemampuan komunikasi S2 lebih rendah dari kemampuan $\mathrm{S} 1$.

Pada hasil analisis tes dan wawancara pada subjek S3 disimpulkan bahwa pada soal 3 sangat terpenuhi kemampuan komunikasi matematinya pada indikator A (S33A) dan C (S33C). Namun, tidak terpenuhi secara keseluruhan pada B dan D.

Tabel 4. Tingkat Kemampuan Matematis pada Siswa S3

\begin{tabular}{ccccccc} 
& \multicolumn{2}{c}{ Soal Nomor $\mathbf{1}$} & \multicolumn{2}{c}{ Soal Nomor 2 } & \multicolumn{2}{c}{ Soal Nomor 3 } \\
\cline { 2 - 7 } Indikator & $\begin{array}{c}\text { Hasil } \\
\text { Analisis }\end{array}$ & Skor & $\begin{array}{c}\text { Hasil } \\
\text { Analisis }\end{array}$ & Skor & $\begin{array}{c}\text { Hasil } \\
\text { Analisis }\end{array}$ & Skor \\
\hline A & ST & 4 & T & 2 & ST & 4 \\
\hline B & T & 2 & ST & 4 & T & 2 \\
\hline C & ST & 4 & ST & 4 & ST & 4 \\
\hline D & TT & 0 & T & 2 & T & 2 \\
\hline Jumlah & T & 10 & ST & 12 & ST & 12
\end{tabular}

Catatan: ST (Sangat terpenuhi), T (Terpenuhi), TT (Tidak Terpenuhi).

Dari tabel 4.6. hasil dari subjek S3 mendapatkan skor sebesar 34 dari analisis tes dan wawancara maka dapat ditarik sebuah kesimpulan bahwa subjek S2 memiliki kemampuan komunikasi matematis yang sangat baik, karena telah memenuhi beberapa indikator mulai dari indikator A, B, C dan D. Berdasarkan dari hasil ketiga soal tersebut S3 memperoleh skor pada soal 1 yaitu sebesar 10 skor, pada soal 2 yaitu 12 skor dan pada soal 3 juga mendapakan 12 skor. Kemampuan komunikasi S1 dan S2 lebih tinggi dari pada kemampuan komunikasi matematis S3.

\section{Pembahasan} penelitian ini.

Berikut ini disajikan tabel analisis hasil tes kemampuan komunikasi matematis pada subjek

Tabel 5. Analisis Kemampuan Komunikasi Matematis pada Subjek

\begin{tabular}{ccc} 
No. Soal & Subjek & Hasil \\
\hline 1 & S3 & 42 \\
\hline 2 & S2 & 38 \\
\hline 3 & S3 & 34
\end{tabular}

Berdasarkan hasil tes kemampuan komunikasi dan wawancara berikut ini adalah analisis pada kemampuan komunikasi matematis siswa dalam menyelesaikan soal HOTS. 
a. Analisis kemampuan komunikasi matematis siswa dalam menyelesaikan soal HOTS pada subjek S1

Berdasarkan dari hasil analisis data yang telah dipaparkan sebelumnya, maka dapat disimpulkan bahwa subjek S1 telah sangat memenuhi semua indikator kemampuan komunikasi matematis pada soal 1, baik secara tertulis maupun secara lisan. Oleh arena itu, subjek mendapatkan skor penuh yaitu 16. S1 menuliskan yang telah diketahui pada soal 1, soal 2 dan soal 3. Maka dari itu, S1 telah mampu memenuhi indikator A (S11A). S1 juga telah mampu menyelesaikan permasalahan yang ada pada semua soal yang telah diberikan mulai dari soal 1, 2 dan 3. S1 menuliskan rumus dan cara kerja pada lembaran jawabannya secara terstruktur dan tepat serta mampu menyebutkannya secara lisan penyelesaian yang telah dikerjakan tersebut. Sehingga S1, sangat memenuhi indikator kemampuan komunikasi matematis yaitu pada indikator B (S11B, S12B, dan S13B).

Serta S1 pun telah memahami simbol-simbol dan notasi yang telah digunakan pada saat menyelesaikan soal tersebut. S1 tidak hanya mampu menuliskan simbol-simbol tapi juga mampu menyebutkan secara lisan ketika diberikan pertanyaan. Sehingga, S1 telah memenuhi indikator C (S11C, S12C dan S13C) yaitu mampu menuliskan dan menyebutkan simbol-simbol dan notasi secara benar. Pada indikator D, yaitu mampu menuliskan dan menyebutkan kesimpulan pada jawaban soal tersebut. S1 sangat memenuhi indikator D pada soal 1 (S11D), karena telah mampu menuliskan secara jelas dan mampu menyebutkan dengan tepat kesimpulan pada jawaban soal1. Sedangkan, pada soal 2 $\mathrm{S} 1$ tidak bisa memenuhi indikator B, karena tidak menuliskan dan tidak menyebutkan secara tepat pada jawabannya. Pada nomor 3 kesimpulan S1 tidak menuliskan secara jelas. Namun menyebutkannya dengan tepat. Subjek S1 secara keseluruhan telah memenuhi kemampuan komunikasi matematis sesuai dengan indikator yang telah ditetapkan dalam menyelesaikan soal Higher Order Thinking Skill (HOTS).

b. Analisis kemampuan komunikasi matematis siswa dalam menyelesaikan soal HOTS pada subjek S2.

Berdasarkan dari hasil analisis data pada tes kemampuan komunikasi matematis siswa dalam menyelesaikan soal HOTS, telah ditemukan bahwa pada tes tertulis dan tes wawancara S2 telah memenuhi kemampuan komunikasi matematis sangat baik. Dibuktikan dengan perolehan skor pada hasi dari analisis yaitu sebesar 38 skor dari 48 skor. Subjek S2 pada hasil analisis soal 1, soal 2, dan soal 3 telah memenuhi dengan sangat pada indikator C kemampuan komunikasi matematis siswa. Hasil analisis data pada indikator A kemampuan komunikasi matematis dalam menyelesaikan soal HOTS maka pada soal 1 dan soal 3, S2 telah menuliskan dan menjawab secara tepat pada bagian diketahui dan ditanyakan dari soal tersebut. Sedangkan pada hasil analisis data soal 2, S2 telah mengungkapkan secara lisan dari apa yang diketahui dan ditanyakan secara tepat dan detail pada soal tersebut. Namun, S2 tidak menuliskan secara keseluruhan yang diketahui dan ditanyakan yang terdapat pada soal tersebut.

Hasil analisi data pada subjek S2, telah memperoleh data yaitu pada indikator B kemampuan komunikasi matematis dalam mengerjakan soal HOTS, pada soal 1 subjek S2 tidak menuliskan cara penyelesaian dari permasalahan yang ada secara tepat hanya menuliskan rumus untuk mencari keliling lingkaran roda kecil dan keliling lingkaran roda besar yaitu $2 \times \pi \times \mathrm{r}$, begitupun S2 juga tidak bisa menyebutkan penyelesaian dari soal tersebut secara sistematis. Sedangkan, pada soal 2 dan soal 3 Subjek S2 telah menyelesaikan cara kerja pada soal tersebut dengan tepat dan sistematis serta juga mampu menyebutkan secara lisan dengan benar. Hasil analisis pada indikator C kemampuan komunikasi matematis siswa yaitu pada subjek S2. Telah terpenuhi secara sempurna dengan baik karena, S2 telah menyebutkan dan telah menuliskan notasi dan simbol-simbol yang digunakan pada saat menyelesaikan soal 1, soal 2 dan soal 3. S2 menuliskan dan menyebutkan notasi dan simbol-simbol yang ada seperti $\mathrm{r}$ melambangkan jari-jari, $\mathrm{K}$ melambangkan keliling, $\mathrm{L}$ melambangkan luas, $\mathrm{d}$ melambangkan diameter, m melambangkan meter dan $\mathrm{cm}$ melambangkan centimeter.

Pada indikator D kemampuan komunikasi matematis siswa dalam menyelesaikan soal HOTS. S2 telah memperoleh data yaitu pada soal nomor 1, S2 tidak mampu menuliskan dan menyebutkan kesimpulan yang ada secara tepat, yaitu tidak mampu menyimpulkan selisih putaran dari roda kecil dengan roda besar. Sedangkan, pada soal 2 dan soal 3 S2 telah mampu menyebutkan dan menuliskan kesimpulan yang tepat pada jawaban soal tersebut. S2 mampu menuliskan dan menyebutkan jarak terjauh dari semprotan salah satu alat tersebut yaitu sepanjang 5 meter pada soal nomor 2, dan S2 juga menuliskan dan menyebutkan luas lahan yang digunakan untuk menanam bunga oleh Pak Tono yaitu sebesar 56,52 meter pada soal 3.

c. Analisis kemampuan komunikasi matematis siswa dalam menyelesaikan soal HOTS pada subjek S3.

Hasil analisis kemampuan komunikasi matematis pada subjek S3 telah meperoleh skor sebesar 32 dari semua indikator kemampuan komunikasi matematis mulai dari total indikator A, B, C dan D. Pada indikator A S3 telah terpenuhi dengan baik pada soal 1 dan 3, karena pada soal 1 NS telah menuliskan 
yang diketahui seperti lintasan lapangan, jari-jari roda kecil, an jari-jari roda besar serta telah menuliskan yang ditanyakan yaitu berapa selisih putaran roda kecil dan roda besar pada soal 1, serta telah menuliskan dan menyebutkan yang diketahui yaitu luas satu kolam renang yaitu sebesar 28, 26 meter serta yang ditanyakan yaitu berapa luas lahan yang digunakan Pak Tono untuk menanam.

Pada hasil analisis B kemampuan komunikasi matematis subjek S3 telah memperoleh skor yaitu pada soal $1 \mathrm{~S} 3$ tidak menyebutkan dan tidak pula menuliskan carakerja sesuai yang dibutuhkan pada soal tersebut yaitu untuk memperoleh selisih putaran roda kecil dan roda besar. Akan tetapi, pada soal 2 dan soal 3 S3 telah menuliskan dan telah menyebutkan cara kerja sesua dengan tujuan soal. S3 menuliskan rumus pada soal nomor 2 yaitu luas lingkaran untuk mencari luas taman yang akan disemprot dan pada soal 2 juga menggunakan rumus luas lingkaran untuk mencari luas tanah yang digunakan menanam bunga. Hasil analisis pada subjek S3 untuk indikator C yaitu telah menyebutkan dan telah menuliskan simbol-simbol yang digunakan untuk menyelesaikan soal 1, soal 2, dan soal 3 . Oleh karena itu, S3 telah memenuhi dengan sangat bai indikator C.

Pada hasil analisis indikator D subjek S3 mendapatkan skor yang tidak terpenuhi dengan baik misalnya pada soal $1 \mathrm{~S} 3$ tidak menuliskan kesimpulannya dan tidak pula menyebutkan kesimpulan yang telah dibutukan pada soal tersebut. Pada soal 2 dan 3 tidak menuliskan kesimpulan yang jelas pada hasil kerja jawabannya hanya saja menyebutkan misalnya pada soal 2 jadi kesimpulannnya yaitu jarak terjauh penyemprotan satu alat yaitu seanjang 5 meter dan pada soal 3 menyebutkan kesimpulannya yaitu luas lahan yang digunakan menanam bunga yaitu 56, 52 meter. Pada soal esai seharusnya S3 menuliskan kesimpulan dengan jelas dan benar biasanya menuliskan pada lembar jawabanya ketika sudah mendapakan hasil akhir seperti misalnya diawali dengan kata jadi, maka, dan sehingga, agar terlihat lebih jelas.

\section{KESIMPULAN}

Dari hasil dan pembahasan tersebut, maka peneliti dapat menyimpulkan bahwa hasil analisis data pada siswa SMP Negeri 13 Makassar dengan memilih subjek S1, S2 dan S3 untuk menganalisis kemampuan komunikasi matematis untuk menyelesaikan soal (HOTS). Pada soal HOTS yang telah dibuat oleh peneliti dan indikator yang telah ditentukan sebelumnya. Maka, S1 telah memperoleh skor sebesar 42 dari skor 48. Dengan memenuhi indikator A, B, dan C dengan sangat baik. Namun, pada indikator D, S1 tidak mampu dengan baik menyebutkan dan menuliskan kesimpulan yang dibutuhkan pada soal. Pada subjek S2 telah mendapatkan 38 skor dari 48 skor. S2 kekurangan 10 skor untuk mendapatkan kemampuan komunikasi matematis secara sempurna. S2 hanya memenuhi kemampuan komunikasi matematis dengan sangat baik pada indikator C untuk semua nomor soal. Pada indikator A, B dan D secara keseluruhan pada soal 1, soal 2 dan soal 3 tidak memenuhi kemampuan komunikasi matematis secara sempurna. Sedangkan pada subjek S3 telah mendapatkan 34 skor dari total 48 skor. S3 juga hanya seperti pada subjek S2 yang hanya indikator $\mathrm{C}$ yang terpenuhi dengan baik pada semua soal, indikator yang lain seperti A, B dan D tidak terpenuhi dengan baik jika ditotalkan secara keseluruhan pada semua soal tersebut. Dari ketiga subjek tersebut maka Subjek S1 telah memperoleh kemampuan komunikasi matematis yang paling tinggi yaitu sebesar 42 skor dan disusul oleh subjek S2 yang memperoleh skor 38 serta yang paling rendah di antara tiga subjek tersebut yaitu subjek S3 yang telah memperoleh 34 skor.

Mengacu pada pemaparan hasil penelitian dari kesimpulan tersebut, sehingga dapat disarankan pada: (a) Guru untuk mengajarkan matematika dengan memakai tata cara yang bisa lebih tingkatkan lagi keterampilan komunikasi matematis siswa ketika mengerjakan soal-soal Higher Order Thinking Skill (HOTS) baik secara lisan ataupun tulisan, (b) Siswa hendaknya selalu melaksanakan pembiasaan dalam mengerjakan soal HOTS serta senantiasa mencermati indikator- indikator kemampuan komunikasi matematis agar pada saat mengerjakan soal bisa menuliskan serta menuturkan permasalahan dengan baik dan sistematis, dan (c) Peneliti lain yang mangulas terkait dengan kemampuan komunikasi matematis siswa supaya lebih memperluas hasil-hasil penelitian ini, tercantum mendapatkan dan menetapkan indikatorindikator kemampuan komunikasi matematis siswa yang belum diungkapkan pada penelitian ini.

\section{REFERENSI}

Kemendikbud. 2018. Modul Penyusunan Soal Higher Order Thinking Skill (HOTS). Dirjen Pendidikan Dasar dan Menengah.

Mandini.W.G. 2018. Analisis Kemampuan Menyelesaikan Soal HOTS Model TIS2S dan Kepercayaan Diri Siswa Sekolah Menengah Pertama. Pythagoras: Jurnal Pendidikan Matematika. Vol 13, No 2.

Permendiknas No 22. Tahun 2016. Tentang Standar Proses. Jakarta: Depdiknas. 
ISSN. 2621-9832

JURNAL MathEdu (Mathematic Education Journal) http://journal.ipts.ac.id/index.php/MathEdu Vol. 4 No. 2 Juli 2021

Permendikbud Nomor 81A. Tahun 2013. Tentang Implementasi Kurikulum Pedoman Umum Pembelajaran. Jakarta: Depdiknas.

Rachmayani, D. 2014. Penerapan Pembelajaran Reciprocal Teaching untuk Meningkatkan Kemampuan Komunikasi Matematis dan Kemandirian Belajar Matematika Siswa. Jurnal Pendidikan Unsika. Vol 2, No 1.

Supriadi, N. 2016. Analisis Kemampuan Komunikasi Matematis Siswa Lamban Belajar dalam Menyelesaikan Soal Bangun Datar. Al-Jabar: Jurnal Pendidikan Matematika. Vol 7, No 1.

Wahyuni, S. 2019. Upaya peningkatan Aktivitas dan prestasi belajar matematika dengan materi luas dan volume kerucut melalui penerapan metode drill di kelas VI SD Negeri Danukulusuman Serangan Surakarta Tahun Pelajaran 2018/2019. Jurnal pendidikan Konvergensi. Vol VII, No 2. 